\title{
Implementasi Data Mining Dengan Menggunakan Algoritma Fuzzy Subtractive Clustering Dalam Pengelompokan Nilai Untuk Menentukan Minat Belajar Siswa Smp Primbana Medan
}

\author{
Yohanni Syahra $^{\# 1}$, M Syahril ${ }^{\# 2}$, Yusnidah ${ }^{\# 3}$ \\ \#1,2 Program Studi Sistem Informasi, STMIK Triguna Dharma \\ \#,3 Universitas Negeri Medan
}

\begin{tabular}{l}
\hline \hline Article Info \\
\hline Article history: \\
Received Jan $10^{\text {th }}, 2018$ \\
Revised Jan $20^{\text {th }}, 2018$ \\
Accepted Jan $29^{\text {th }}, 2018$ \\
\hline
\end{tabular}

\section{Keyword:}

Minat Belajar

Data Mining

Fuzzy Subtractive Clustering

\begin{abstract}
Dalam dunia pendidikan, sebuah unit yang sangat menunjang kelancaran proses belajar mengajar adalah bagian administrasi. Hilir mudiknya arus proses administrasi baik keuangan maupun proses memasukkan nilai siswa tampaknya menjadi hal penting yang harus dikelola dengan baik. Untuk memudahkan pengaturan ini langkah terbaik diambil adalah penggunaan sistem komputerisasi, karena mengikuti perkembangan teknologi yang semakin pesat sampai saat ini. Tujuan penelitian ini adalah untuk menentukan minat belajar siswa berdasarkan nilai siswa. Penelitian yang dilakukan dalam hal ini adalah penelitian deskriptif dan kualitatif dengan melakukan survei terhadap objek penelitian yaitu pada SMP Primbana Medan dengan menggunakan teknik pengumpulan data yaitu Sistem yang dibuat berdasarkan metode Fuzzy Subtractive Clustering dan sistem database dengan menggunakan Microsoft Office Access 2007 dan Microsoft Visual Basic 2008 sebagai bahasa pemrogramannya, sehingga proses pengolahan data dan penyajian laporan minat belajar sesuai dengan yang diharapkan. Data yang dihasilkan dibuat dalam laporan data siswa yang mempunyai minat belajar rendah. Dengan demikian proses belajar mengajar siswa lebih tertata dan siswa yang memiliki minat belajar tersebut pun lebih diperhatikan oleh guru yang mengajar.
\end{abstract}

Copyright $@ 2018$ STMIK Triguna Dharma. All rights reserved.

\begin{tabular}{ll}
\hline First Author & \\
Nama & : Yohanni Syahra, S.Si, M.Kom \\
Kantor & : STMIK Triguna Dharma \\
Program Studi & : Sistem Komputer \\
E-Mail & : yohanni.syahra@ gmail.com
\end{tabular}

\section{PENDAHULUAN}

Pendidikan merupakan salah satu aspek pembangunan bangsa yang sangat penting untuk mewujudkan pengembangan sumber daya manusia dan watak bangsa. Oleh karena itu pendidikan anak sejak usia dini sangat penting untuk meningkatkan kecerdasan anak yang merupakan dasar untuk pengembangan diri selanjutnya untuk mendapat nilai terbaik dalam proses belajar mengajar.

Nilai siswa merupakan komponen penting dalam sistem pembelajaran di sekolah, karena nilai siswa menjadi salah satu tolak ukur penguasaan materi pelajaran oleh siswa. Nilai siswa juga menjadi acuan untuk pengambilan keputusan kenaikan kelas. Selain itu, nilai siswa menjadi bahan evaluasi hasil belajar bagi orangtua siswa.

Data nilai siswa perlu dikelompokkan untuk membedakan nilai yang baik dan buruk dengan jangkauan kelompok nilai tertentu. Hasil pengelompokan nilai ini dapat digunakan untuk membuat suatu kebijakan pembelajaran di sekolah. Kebijakan tersebut dapat berupa pembenahan metode pengajaran, pembenahan sistem penilaian, atau pengukuran tingkat keberhasilan guru dalam menyampaikan materi pelajaran.

Minat adalah kecenderungan yang menetap dalam subjek untuk merasa tertarik pada bidang atau hal tertentu dan merasa senang berkecimpung dalam bidang itu (Winkel, 1984:30). Adanya suatu ketertarikan yang sifatnya 
tetap di dalam diri subjek atau seseorang yang sedang mengalaminya atas suatu bidang atau hal tertentu dan adanya rasa senang terhadap bidang atau hal tersebut, sehingga seseorang mendalaminya.

Dari pendapat yang dikemukakan oleh para ahli tersebut, dapat disimpulkan bahwa minat belajar adalah suatu dorongan atau gairah yang tinggi dalam hal pemusatan perhatian terhadap kegiatan belajar melalui interaksi dengan lingkungannya dan akan menimbulkan perubahan prilaku.

Pengelompokan (Clustering) merupakan salah satu teknik yang paling penting dalam Data Mining. Salah satu metode pengelompokan yang paling sering digunakan adalah Fuzzy C-Means. Metode Fuzzy C-Means memiliki beberapa karakteristik, antara lain membutuhkan banyaknya kelompok dan matriks keanggotaan kelompok yang ditetapkan sebelumnya. Biasanya, matriks keanggotaan kelompok awal diinisialisasikan secara acak yang menyebabkan metode Fuzzy C-Means memiliki kerumitan.

Alternatif metode pengelompokan lainnya yang dapat digunakan jika jumlah kelompok tidak diketahui sebelumnya adalah metode Substractive Clustering. Substractive Clustering memperoleh hasil yang lebih konsisten dibandingkan dengan Fuzzy C-Means. Selain itu, Substractive Clustering memiliki kecepatan yang lebih baik dibandingkan Fuzzy C-Means, namun Substractive Clustering memiliki akurasi yang lebih rendah dibandingkan dengan Fuzzy C-Means.

Database yang dikenal dengan istilah Knowledge Discovery in Database (KDD) (Sutrisno, dkk. 2013). Teknik Data Mining yang digunakan untuk mencari segmentasi konsumen adalah menggunakan teknik clustering. Teknik clustering digunakan pada Data Mining untuk mengelompokkan 3 objek-objek yang memiliki kemiripan dalam kelas atau segmen yang sama, sementara objek-objek yang terletak pada kelas yang berbeda menunjukkan karakteristik yang berbeda juga.

\section{METODE PENELITIAN}

\subsection{Knowledge Discovery in Database}

Secara sederhana Data Mining adalah bagaimana menelusuri data yang ada untuk membangun sebuah model, kemudian menggunakan model tersebut agar dapat mengenali pola data yang lain yang tidak berada dalam basis data yang tersimpan (Eko Prasetyo, 2012:2). Data mining adalah proses yang mempekerjakan satu atau lebih teknik pembelajaran komputer (machine learning) untuk menganalisis dan mengekstraksi pengetahuan (knowledge) secara otomatis (Fajar Astuti Hermawati, 2009:3). Defenisi lain diantaranya adalah pembelajaran berbasis induksi (induction-based learning) adalah proses pembentukan defenisi-defenisi konsep umum yang dilakukan dengan cara mengobservasi contoh-contoh spesifik dari konsep-konsep yang akan dipelajari. Knowledge Discovery In Database (KDD) adalah penerapan metode saintifik pada Data Mining. Dalam konteks ini Data Mining merupakan satu langkah dari proses KDD (Fajar Astuti Hermawati, 2009:3).

Data Mining juga disebut sebagai serangkaian proses untuk menggali nilai tambah berupa pengetahuan yang selama ini tidak diketahui secara manual dari suatu kumpulan data (Data Mining, sering juga disebut sebagai Knowledge Discovery In Database (KDD). KDD bertujuan untuk memanfaatkan data dalam basis data dengan dengan mengolahnya sehingga menghasilkan informasi baru yang sempurna (Prasetyo Eko, 2014; 1$2)$.

Mining dapat dibagi menjadi beberapa tahap yang diilustrasikan di Gambar 2.1. Tahap-tahap tersebut bersifat interaktif,pemakai terlibat langsung atau dengan perantaraan knowledge base. 


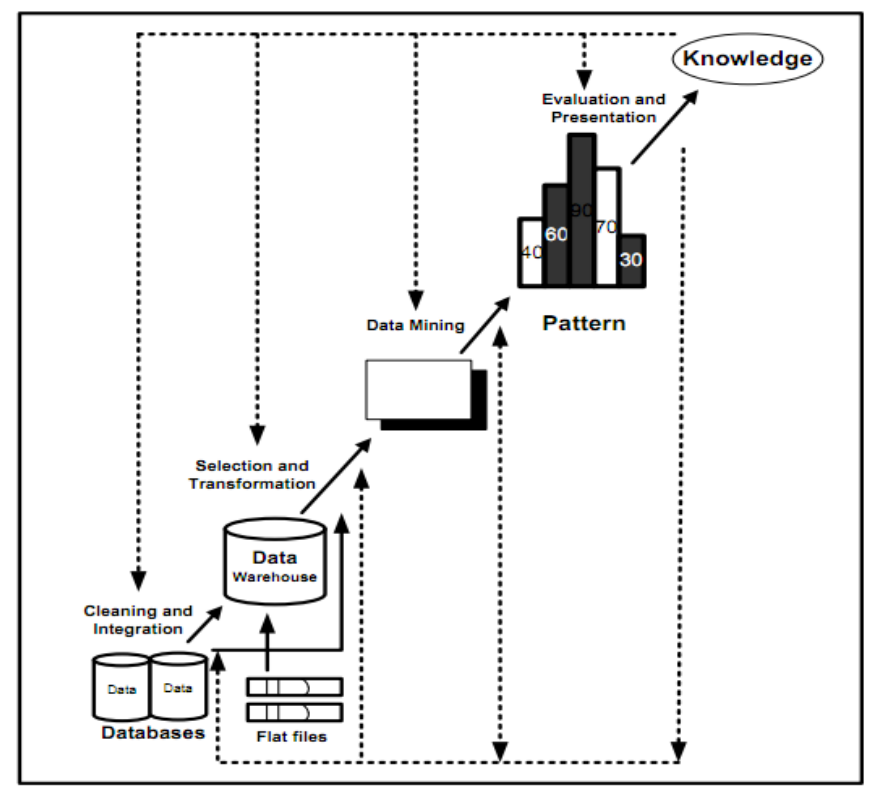

Gambar 1.Tahap-Tahap Data Mining (Han, 2006).

Tahap-tahap Data Mining ada 6 yaitu :

1. Pembersihan data (Data Cleaning)

Pembersihan data merupakan proses menghilangkan noise dan data yang tidak konsisten atau data tidak relevan. Pada umumnya data yang diperoleh, baik dari database suatu perusahaan maupun hasil eksperimen, memiliki isian-isian yang tidak sempurna seperti data yang hilang, data yang tidak valid atau juga hanya sekedar salah ketik. Selain itu, ada juga atribut-atribut data yang tidak relevan dengan hipotesa Data Mining yang dimiliki. Data-data yang tidak relevan itu juga lebih baik dibuang. Pembersihan data juga akan mempengaruhi performasi dari teknik Data Mining karena data yang ditangani akan berkurang jumlah dankompleksitasnya.

2. Integrasi data (Data Integration)

Integrasi data merupakan penggabungan data dari berbagai database ke dalam satu database baru. Tidak jarang data yang diperlukan untuk data mining tidak hanya berasal dari satu database tetapi juga berasal dari beberapa database atau file teks. Integrasi data dilakukan pada atribut-aribut yang mengidentifikasikan entitas-entitas yang unik seperti atribut nama, jenis produk, nomor pelanggan dan lainnya. Integrasi data perlu dilakukan secara cermat karena kesalahan pada integrasi data bisa menghasilkan hasil yang menyimpang dan bahkan menyesatkan pengambilan aksi nantinya. Sebagai contoh bila integrasi data berdasarkan jenis produk ternyata menggabungkan produk dari kategori yang berbeda maka akan didapatkan korelasi antar produk yang sebenarnya tidak ada.

3. Seleksi Data (Data Selection)

Data yang ada pada database sering kali tidak semuanya dipakai, oleh karena ituhanya data yang sesuai untuk dianalisis yang akan diambil dari database.

4. Transformasi data (Data Transformation)

Data diubah atau digabung ke dalam format yang sesuai untuk diproses dalam Data Mining. Beberapa metode Data Mining membutuhkan format data yang khusus sebelum bisa diaplikasikan. Sebagai contoh beberapa metode standar seperti analisis asosiasi dan Clustering hanya bisa menerima input data kategorikal. Karenanya data berupa angka numerik yang berlanjut perlu dibagi-bagi menjadi beberapa interval. Proses ini sering disebut transformasi data.

5. Proses Mining

Merupakan suatu proses utama saat metode diterapkan untuk menemukan pengetahuan berharga dan tersembunyi dari data.

6. Evaluasi pola (Pattern Evaluation),

Untuk mengidentifikasi pola-pola menarik kedalam Knowledge Based yang ditemukan. Dalam tahap ini hasil dari teknik Data Mining berupa pola-pola yang khas maupun model prediksi dievaluasi untuk menilai apakah hipotesa yang ada memang tercapai. Bila ternyata hasil yang diperoleh tidak sesuai hipotesa ada beberapa alternatif yang dapat diambil seperti menjadikannya umpan balik untuk memperbaiki proses Data Mining, mencoba Data Mining lain yang lebih sesuai, atau menerima hasil ini sebagai suatu hasil yang di luar dugaan yang mungkin bermanfaat.

7. Presentasi pengetahuan (Knowledge Presentation), 
Merupakan visualisasi dan penyajian pengetahuan mengenai metode yang digunakan untuk memperoleh pengetahuan yang diperoleh pengguna. Tahap terakhir dari proses Data Mining adalah bagaimana memformulasikan keputusan atau aksi dari hasil analisis yang didapat. Ada kalanya hal ini harus melibatkan orang-orang yang tidak memahami Data Mining. Karenanya presentasi hasil Data Mining dalam bentuk pengetahuan yang bisa dipahami semua orang adalah satu tahapan yang diperlukan dalam proses Data Mining. Dalam presentasi ini,visualisasi juga bisa membantu mengkomunikasikan hasil Data Mining (Han,2006).

\subsection{Data Mining}

Data Mining adalah serangkaian proses untuk menggali nilai tambah dari suatu kumpulan data berupa pengetahuan yang selama ini tidak diketahui secara manual. Patut diingat bahwa kata mining sendiri berarti usaha untuk mendapatkan sedikit barang berharga dari sejumlah besar material dasar. Karena itu Data Mining sebenarnya memiliki akar yang panjang dari bidang ilmu seperti kecerdasan buatan (artificial intelligent), machine learning, statistic dan database.

Data Mining adalah proses menerapkan metode ini untuk data dengan maksud untuk mengungkap polapola tersembunyi. Dengan arti lain Data mining adalah proses untuk penggalian pola-pola dari data. Data mining menjadi alat yang semakin penting untuk mengubah data tersebut menjadi informasi. Hal ini sering digunakan dalam berbagai praktek profil, seperti pemasaran, pengawasan, penipuan deteksi dan penemuan ilmiah. Telah digunakan selama bertahun-tahun oleh bisnis, ilmuwan dan pemerintah untuk menyaring volume data seperti catatan perjalanan penumpang penerbangan, data sensus dan supermarket scanner data untuk menghasilkan laporan riset pasar. Alasan utama untuk menggunakan Data Mining adalah untuk membantu dalam analisis koleksi pengamatan perilaku. Data tersebut rentan terhadap Collinearity karena diketahui keterkaitan.

Fakta yang tak terelakkan Data Mining adalah bahwa subset/set data yang dianalisis mungkin tidak mewakili seluruh domain, dan karenanya tidak boleh berisi contoh-contoh hubungan kritis tertentu dan perilaku yang ada di bagian lain dari domain. Untuk mengatasi masalah semacam ini, analisis dapat ditambah menggunakan berbasis percobaan dan pendekatan lain, seperti Choice Modelling untuk data yang dihasilkan manusia. Dalam situasi ini, yang melekat dapat berupa korelasi dikontrol untuk, atau dihapus sama sekali, selama konstruksi desain eksperimental.

Beberapa teknik yang sering disebut-sebut dalam literatur Data Mining dalam penerapannya antara lain: clustering, classification, association rule mining, neural network, genetic algorithm dan lain-lain. Yang membedakan persepsi terhadap Data Mining adalah perkembangan teknik-teknik Data Mining untuk aplikasi pada database skala besar. Sebelum populernya Data Mining, teknik-teknik tersebut hanya dapat dipakai untuk data skala kecil saja.

\subsection{Fuzzy Subtractive}

Fuzzy Subtractive Clustering adalah algoritma clustering yang terawasi, sebab pada Fuzzy Subtractive Clustering kita harus terlebih dahulu menentukan banyaknya cluster yang akan dibentuk. Menentukan banyaknya cluster yang tepat merupakan permasalahan utama dalam pendekatan ini menurut Geva dalam Kusumadewi \& Purnomo (2004,39). Apabila banyaknya cluster belum diketahui, maka kita harus menggunakan algoritma yang takterawasi (banyaknya cluster ditentukan oleh algoritma). Fuzzy Subtractive Clustering merupakan algoritma cluster yang tak terawasi yang diperkenalkan pertama kali oleh Chiu pada tahun 1994 menurut Chiu dalam Kusumadewi \& Purnomo $(2004,39)$.

Algoritma Subtractive Clustering dibangun berdasarkan Ukuran kepadatan (density) titik data dalam suatu ruang (Perubah). Konsep dasar Subtractive Clustering adalah menentukan daerah perubah yang dimiliki data yang tinggi. Titik dengan jumlah tetangga terbanyak akan dipilih sebagai pusat cluster. Titik yang terpilih akan dikurangi tingkat kepadatannya. Kemudian algoritma akan memilih titik lain yang memiliki tingkat kepadatan tertinggi lainnya untuk dijadikan sebagai pusat cluster yang lain Kusumadewi \& Purnomo dalam Yanti Novita ( 2004,39).

Tahap-tahap Algoritma Fuzzy Subtractive clustering adalah sebagai berikut menurut Kusumadewi \& Purnomo dalam Yanti novita(2006,42) :

1. Tentukan $X_{i j}$ sebagai input data yang akan dicluster, berukuran $\mathrm{i} \times \mathrm{j}$, dengan $\mathrm{i}=$ jumlah data yang akan di-cluster dan $\mathrm{j}=$ jumlah variabel/atribut (kriteria).

2. Menentukan:
a. $\quad r_{j}$ (jari-jari setiap atribut data);
b. $j=1,2, \ldots, m$.
c. $q$ (squash factor).
d. accept ratio
e. reject ratio.
f. $X_{\min }$ (min data yang diperbolehkan dalam setiap atribut data) $; j=1,2, \ldots, m$.
g. $X_{\max _{j}}$ (max data yang diperbolehkan dalam setiap atribut data) $; j=1,2, \ldots, m$. 
3. Normalisasi :

$$
X_{i j}=\frac{X_{\mathrm{ij}}-\mathrm{X} \min _{\mathrm{j}}}{\mathrm{Xmax}_{\mathrm{j}}-\mathrm{Xmin}_{\mathrm{j}}}
$$

4. Tentukan potensi awal tiap-tiap titik data

a. $i=1 ; i$ adalah data ke 1 .

b. Kerjakan hingga $i=n$,

$$
\operatorname{Dist}_{k j}=\left(\frac{T_{j-X_{k j}}}{r_{j}}\right)
$$

5. Cari titik dengan potensi tertinggi

a. $M=\max [\mathrm{Di} \mid \mathrm{i}=1,2, \ldots, n]$

b. $h=i$, sedemikian hingga $D_{i}=M$

\section{ANALISIS DAN HASIL}

\subsection{Analisis}

Nilai siswa merupakan komponen penting dalam sistem pembelajaran di sekolah, karena nilai siswa menjadi salah satu tolak ukur penguasaan materi pelajaran oleh siswa. Nilai siswa juga menjadi acuan untuk pengambilan keputusan kenaikan kelas. Selain itu, nilai siswa menjadi bahan evaluasi hasil belajar bagi orang tua siswa.

Data nilai siswa perlu dikelompokkan untuk membedakan nilai yang baik dan buruk dengan jangkauan kelompok nilai tertentu. Hasil pengelompokan nilai ini dapat digunakan untuk membuat suatu kebijakan pembelajaran di sekolah. Kebijakan tersebut dapat berupa pembenahan metode pengajaran, pembenahan sistem penilaian, atau pengukuran tingkat keberhasilan guru dalam menyampaikan materi pelajaran.

Pengelompokan (clustering) merupakan salah satu teknik yang palingpenting dalam data mining. Salah satu metode pengelompokan yang paling sering digunakan adalah Fuzzy C-Means. Metode Fuzzy C-Means memiliki beberapa kelemahan, antara lain membutuhkan banyaknya kelompok dan matriks keanggotaan kelompok yang ditetapkan sebelumnya. Biasanya, matriks keanggotaan kelompok awal diinisialisasikan secara acak yang menyebabkan metode Fuzzy C-Means memiliki masalah inkonsistensi.

Alternatif metode pengelompokan lainnya yang dapat digunakan jika jumlah kelompok tidak diketahui sebelumnya adalah metode Substractive Clustering. Substractive Clustering memperoleh hasil yang lebih konsisten dibandingkan dengan Fuzzy C-Means. Selain itu, Substractive Clustering memiliki kecepatan yang lebih baik dibandingkan Fuzzy C-Means, namun Substractive Clustering memiliki akurasi yang lebih rendah dibandingkan dengan Fuzzy C-Means.

Analisis kebutuhan data dilakukan pada SMP Primbana Medan untuk menentukan pengelompokan nilai siswa berdasarkan kemampuan dan nilai yang didapat seperti nilai Exact seperti IPA, Mate-Matika sedangkan Non Exact meliputi nilai B.Indonesia, PKN, TIK, sedangkan Muatan Lokal terdiri dari PJOK, Bahasa Inggris dan SBK.

Pada penelitian ini, data yang digunakan adalah dari data sisiwa tentang minat belajar pada tingkat SMP Primbanan Medan. Angka-angka tersebut diperoleh dari hasil nilai yang didapat selama satu semester dan dikelompokan dalam 3 bagian yaitu nilai Exact nilai Non Exact dan nilai Muatan Lokal.

Subtractive Fuzzy C-Means merupakan penggabungan antara metode pengelompokan Subtractive Clustering dan Fuzzy C-Means. Subtractive Clustering digunakan untuk menentukan jumlah kelompok dan matriks keanggotaan awal Fuzzy $C$-Means sehingga inisialisasi secara random tidak perlu dilakukan. Secara garis besar Algoritma Metode Subtractive Fuzzy C-Means adalah sebagai berikut :

Langkah awal proses pengelompokan dengan Fuzzy Subtractive Clustering adalah normalisasi data. Tujuan dari normalisasi data adalah untuk menyamakan jangkauan antara variabel Exact, non Exact, dan Muatan Lokal yang berbeda. maka hasil nilai siswa dari minat belajar seperti pada tabel dibawah ini:

Setelah menentukan nilai minat siswa dalam tiga clustering maka langkah selanjutnya mengnormalisasi data nilai minat siswa yang dihitung dengan rumus berikut ini:

1. Ade Kenia Ginting

$$
X_{i j}=\frac{X_{i j}-X \min _{j}}{X \max _{j}-X \min _{j}}, i=1,2, \ldots, n ; j=1,2, \ldots, m
$$


Exact

$$
\begin{aligned}
& =X_{i j}=\frac{85-75}{91-75}=0.65 \\
& =X_{i j}=\frac{89-77}{97-77}=0.62
\end{aligned}
$$

Non Exact

Muatan Lokal $=X_{i j}=\frac{87-78}{93-78}=0.62$

2. Adji Wibowo

$$
\begin{aligned}
& \text { Exact }=X_{i j}=\frac{77-75}{91-75}=0.11 \\
& \text { Non Exact }=X_{i j}=\frac{85-77}{97-77}=0.43 \\
& \text { Muatan Lokal }=X_{i j}=\frac{82-78}{93-78}=0.28
\end{aligned}
$$

Setelah didapatkan data yang ternormalisasi, langkah selanjutnya adalah menentukan nilai potensi awal tiap-tiap data kemudian mencari data dengan nilai potensi terbesar yang terpilih sebagai pusat kelompok pertama. Potensi awal tiap-tiap data dihitung menggunakan rumus sebagai berikut:

Setelah melakukan Normalisasi data, maka langkah selanjutnya adalah menghitung potensi awal dari setiap data seperti berikut ini:

Keterangan :

$$
\operatorname{Dist}_{k j}=\frac{\left|T_{j}-X_{k j}\right|}{r_{j}}
$$

Dist $_{k \mathrm{j}}=$ merupakan potensi Awal

$T_{j}=X_{i j}\left(T_{j}\right.$ merupakan data ke- $i$ atribut ke- $\left.j\right)$

$X k_{j}$ adalah data ke- $y$

$r_{a}$ adalah konstanta positif yang dikenal dengan nama jari-jari. Dimana nilai $r$ ditentukan terlebih dahulu 0.3

1. Ade Kenia Ginting

Exact $=\frac{[0,99-0,64]}{0.3}=1,15$

Non Exact $=\frac{[0,98-0,38]}{0.3}=1,27$

Muatan Lokal $=\frac{[1,02-0,40]}{0.3}=1,33$

Dengan nilai potensi awal terbesar exact terdapat pada data ke-16 dengan nilai potensi awal terbesar 3.33.non exact terdapat pada data ke 50 dengan nilai 3.32. muatan lokal terdapat pada data ke 50 dengan nilai 3.47 sehingga data ke 16 dan 50 dipilih sebagai pusat kelompok pertama. Langkah berikutnya adalah mengurangi potensi data di sekitar pusat kelompok pertama. Untuk menghitung potensi baru seperti pada rumus dibawah ini:

$$
P_{k}=\frac{\left\|X_{k}-X_{c}\right\|^{2}}{r}
$$

dimana nilai $r=0.3$ jadi untuk mencari nilai potensi baru seperti dibawah ini:

$$
\text { 1. Ade Kenia Ginting }
$$

Exact $=\frac{[3.33-1.15]}{0.3}=7.25$

Non Exact $=\frac{[3.32-1.27]}{0.3}=6.84$

Muatan Lokal $=\frac{[3.47-1.33]}{0.3}=7.15$

Nilai Ratio dihitung dari hasil bagi potensi baru dengan potensi awal Exact yaitu ratio $=\frac{11.10}{3.33}=3.3319$. Karena nilai ratio > accept ratio. Sebagai Minat Belajar terendah. Non exact yaitu ratio $=\frac{11.10}{3.32}=3.3445$. Karena nilai ratio $>$ accept ratio. Muatan lokal yaitu ratio $=\frac{11.10}{3.47}=3.3404$. Karena nilai ratio $>$ accept ratio. . Maka siswa yang memiliki minat belajar yang paling rendah seperti dibawah ini.

Tabel 1. data siswa yang memiliki minat belajar rendah

\begin{tabular}{|c|l|c|c|c|}
\hline No & Nama Siswa & Exact & Non Exact & $\begin{array}{c}\text { Muatan } \\
\text { Lokal }\end{array}$ \\
\hline 1 & Mutiara Rismayanti br Pasaribu & 0,01 & 2,21 & 0,74 \\
\hline 2 & Raihan Sipayung & 2,78 & $-0,01$ & $-0,01$ \\
\hline 3 & Harry Versat & 2,08 & 2,22 & 0,00 \\
\hline 4 & Andre Gabriel Ginting & 1,39 & 1,67 & 0,00 \\
\hline 5 & Serwen singh & 1,39 & 4,44 & 0,00 \\
\hline
\end{tabular}

Jika ratio < reject ratio. maka sudah tidak ada lagi data yang dipertimbangkan untuk menjadi calon pusat kelompok dan iterasi berhenti. 
Dengan hasil tabel diatas maka di dapatkan siswa-siswi yang memiliki minat belajar rendah. Oleh karena itu diharapkan kepada guru-guru yang bersangkutan untuk lebih memperhatikan siswa yang memiliki minat belajar rendah tersebut.

Flowchart Sistem merupakan keterangan yang lebih rinci tentang bagaimana sebenarnya prosedur yang dilakukan suatu sistem dalam menentukan minat belajar siswa. Flowchart ini menggambarkan urutan logika dari suatu prosedur pemecahan masalah. Adapun flowchart pada program ini. seperti yang terlihat pada gambar dibawah ini.

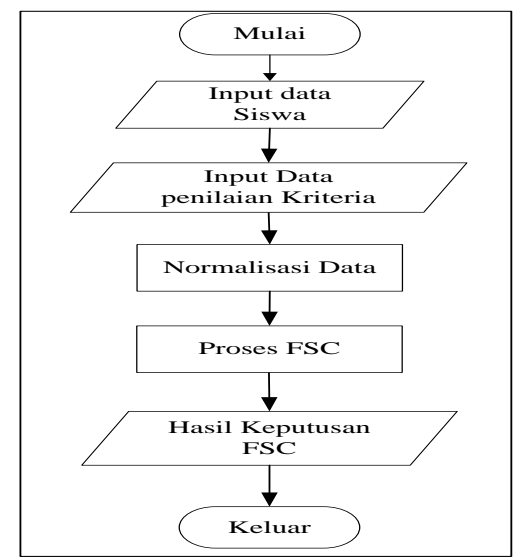

Gambar 2. Flowchart Sistem Metode FSC

Pemodelan yang digunakan dalam penelitian ini dengan Unified Modeling Language (UML) adalah sebuah bahasa yang telah menjadi standar dalam industri untuk visualisasi. merancang dan mendokumentasi perangkat lunak. Dalam perancangan ini menggunakan Use Case Diagram yaitu menggunakan fungsionalitas yang diharapkan dari sebuah sistem. Use Case merepresentasikan sebuah interaksi antara aktor dengan sistem. Seorang aktor adalah sebuah entitas manusia atau mesin yang berinteraksi dengan sistem untuk melakukan pekerjaan-pekerjaan tertentu

Use case diagram adalah gambaran dari beberapa atau semua actor. use case. dan interkasi diantara komponen-komponen tersebut yang memperkenalkan suatu sistem yang akan dibangun. Use case diagram menjelaska manfaat suatu sistem jika dilihat menurut pandangan orang yang berada diluar sistem. Diagram ini menunjukkan fungsionalitas suatu sistem atau kelas dan bagaimana sistem tersebut berinteraksi dengan dunia luar. Berikut adalah model use case diagram pada sistem pendukung keputusan dalam menentukan minat belajara siswa. maka dibuatlah use case diagram seperti pada gambar dibawah ini:

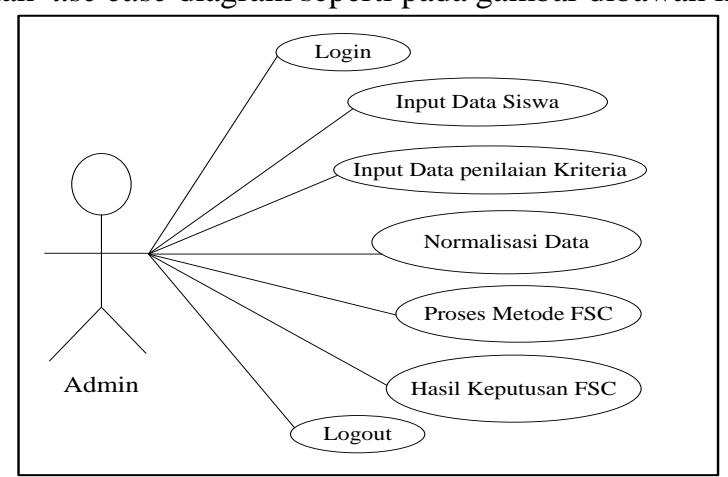

Gambar 3. Use Case Diagram Metode FSC

Pada gambar activity diagram dibawah menunjukan bahwa user mengendalikan semua sistem yang telah dibuat. dimana user pertama-tama memproses dengan mengimput data kriteria. lalu memproses dengan metode Fuzzy Subtractive Clustering sehingga menghasilkan sebuah keputusan dalam menentukan minat belajar siswa. gambar activity diagram yang dirancang dapat dilihat pada gambar dibawah ini: 


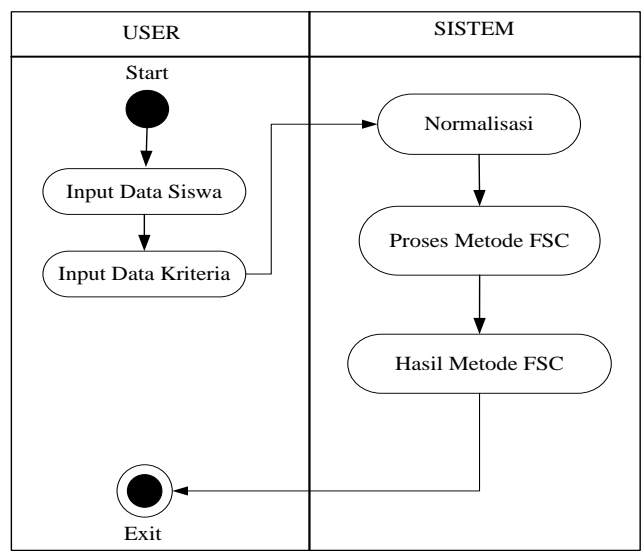

Gambar 4. Activity Diagram Metode FSC

Diagram yang digunakan untuk menampilkan beberapa kelas serta paket-paket yang ada dalam sistem/perangkat lunak yang sedang kita kembangkan. Class Diagram memberikan gambaran sistem secara statis dan relasi antar atribut. Biasanya. dibuat beberapa class diagram untuk sistem tunggal. Beberapa diagram akan menampilkan subset dari kelas-kelas dan relasinya. dalam menentukan minat belajar siswa maka dibuatlah sebuah class diagram seperti pada gambar dibawah ini:

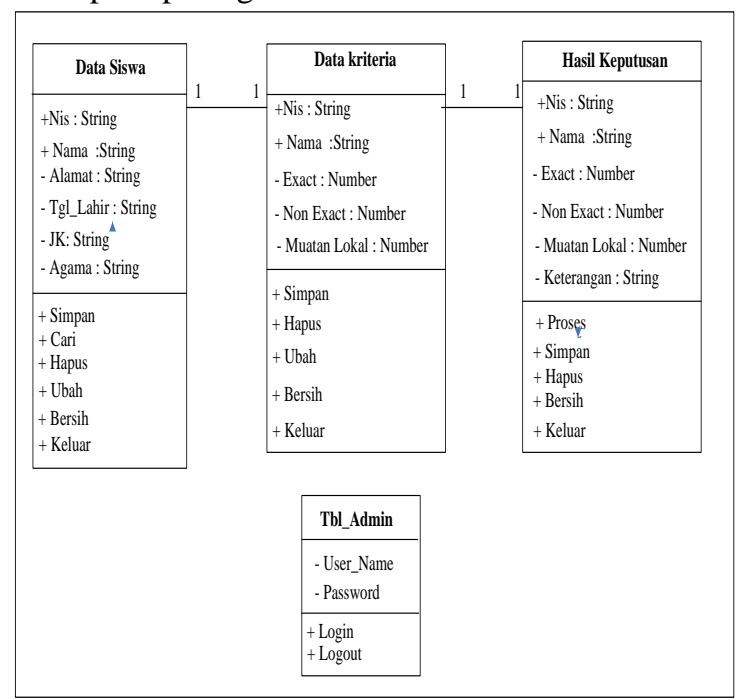

\subsection{Hasil}

Gambar 5. Class diagram

Pada implementasi ini, data yang digunakan adalah data siswa kelas IX pada SMP Primbana Medan. Data tersebut dibuat dalam Microsoft Excel 2010.

Form Login merupakan tampilan yang digunakan admin untuk membuka hak akses terhadap menu yang masih terkunci, berikut adalah tampilannya.

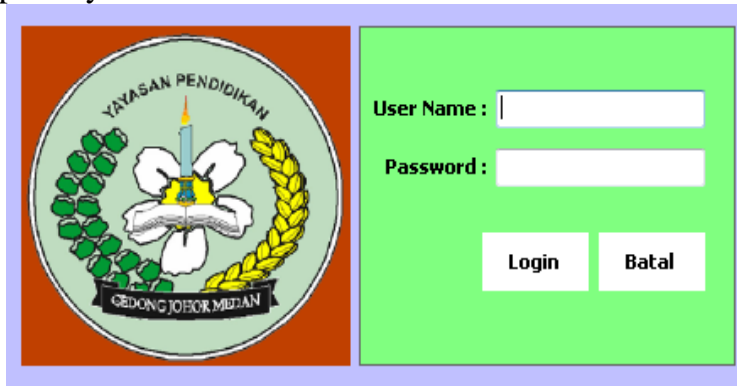

Gambar 6. Tampilan Form Login

Form utama merupakan form yang digunakan untuk memanggil semua informasi sub form yang ada di dalam aplikasi, berikut adalah tampilannya. 


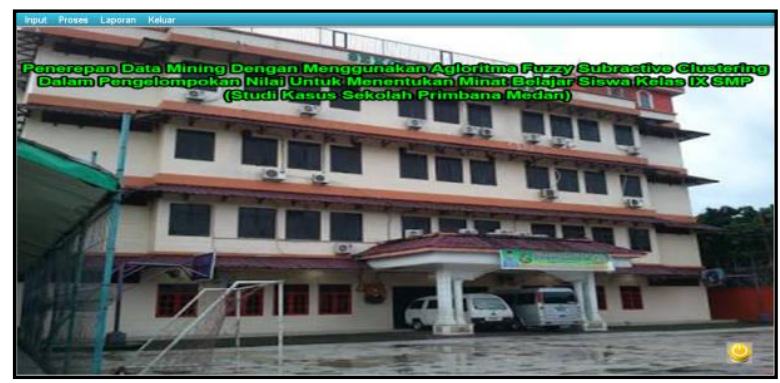

Gambar 7. Tampilan Menu Utama

Form data siswa merupakan yang digunakan untuk memasukkan data siswa, berikut adalah tampilannya.

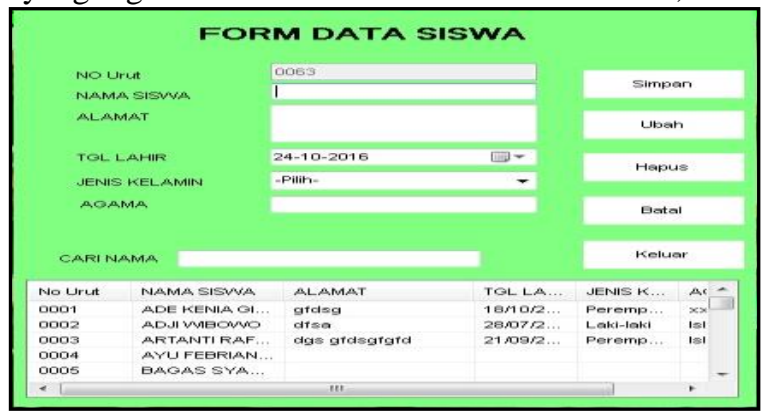

Gambar 8. Tampilan Form Data Siswa

Form data cluster merupakan yang digunakan untuk menampilkan data nilai yang sudah di cluster, berikut adalah tampilannya.

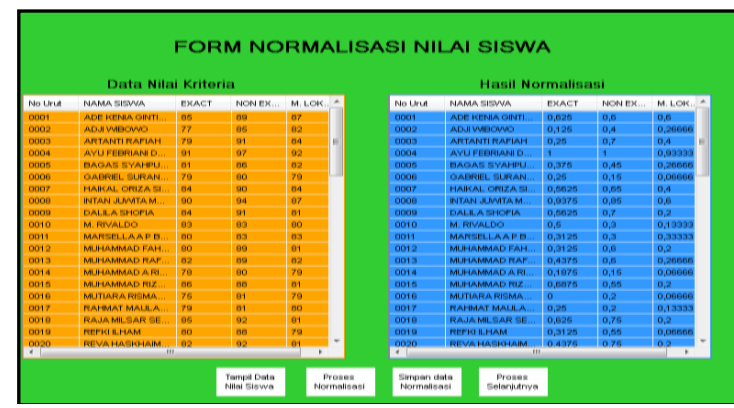

Gambar 9. Tampilan Data Cluster Nilai

Form hasil laporan ini digunakan sebagai hasil akhir siswa yang memiliki minat belajar yang paling rendah. Tampilan hasil laporan keputusan dapat dilihat pada gambar di bawah ini.

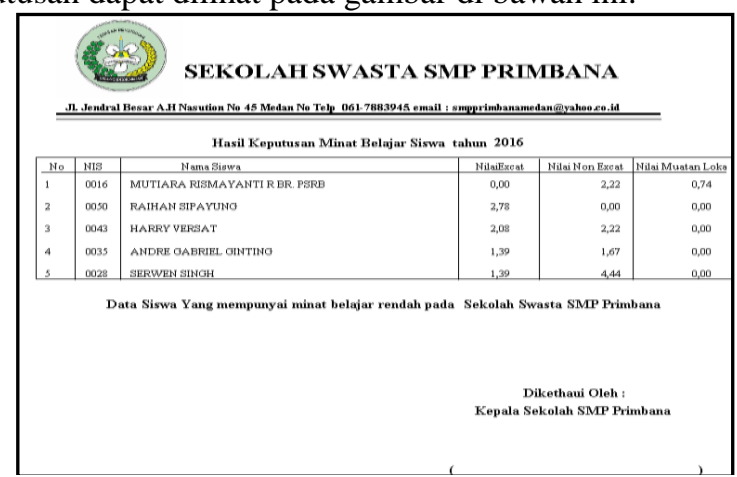

Gambar 10.0 Tampilan Hasil Laporan

\section{KESIMPULAN}

Berdasarkan Implementasi yang dilakukan maka dapat disimpulkan sebagai berikut :

1. Hasil dari pengelompokan nilai Data Mining yang diterapkan ini akan menghasilkan keluaran nilai ranking untuk siswa yang minat belajarnya kurang khususnya untuk siswa kelas IX SMP.

2. Dengan program yang dirancang, pada aplikasi Penerapan Data Mining Dengan Menggunakan Algoritma Fuzzy Subtractive Clustering Dalam Pengelompokan Nilai Untuk Menentukan Minat Belajar Siswa Kelas 
IX SMP dapat memudahkan sekolah primbana untuk mengelompokan data nilai minat belajar bagi siswa.

3. Dengan menggunakan Data Mining nilai siswa mudah dikelompokkan

\section{DAFTAR PUSTAKA}

[1] Kusrini \& Lutfi Taufik Emha 2011. Data Mining. Yogyakarta: Andi.

[2] Lee Christopher. 2014. Buku Pintar Visual Basic 2010. Jakarta: PT Elex Media Komputindo

[3] S, Rosa A. \& M. Shalahuddin. 2015. Rekayasa Perangkat Lunak Terstruktur dan Berorientasi Objek. Bandung: Informatika.

[4] Sri Kusumadewi dan Purnomo Hari.2010. Aplikasi Logika Fuzzy.Yogyakarta: Graha Ilmu.

[5] Wahana Komputer 2010. Belajar pemrograman Visual Basic 2010 Yogyakarta: Andi

\section{BIOGRAFI PENULIS}

\begin{tabular}{|l|l|} 
Yohanni Syahra, S. Si., M. Kom, Perempuan kelahiran Medan, 29 Oktober 1982 saat ini beliau \\
menduduki jabatan Sekretaris Program Studi Sistem Informasi STMIK Triguna Dharma, tamat \\
Universitas Sumatera Utara Bidang Ilmu Kimia, tamat Universitas Putra Indonesia (UPI-YPTK) \\
Konsentrasi Teknologi Komputer, beberapa mata kuliah diampu, diantaranya : Data Mining Dan \\
Data Warehouse, Sistem Pakar, Komputer Multimedia, Komputer Akuntansi, Sistem Basis Data, \\
Aplikasi Finansial, Paket Program Niaga.
\end{tabular}

